\title{
Barriers to Prevention of HIV Transmission from Mother to Child (PMTCT) in a Resource poor Setting in the Eastern Cape, South Africa
}

\author{
Karl Peltzer*, Thabang Mosala**, Olive Shisana**, Ayanda Nqueko**, and Nolwandle Mngqundaniso**
}

\begin{abstract}
The aim of this study was to investigate knowledge of PMTCT and to describe potential barriers that might affect acceptability of interventions for PMTCT in a resource poor setting in South Africa. The sample included 1534 pregnant women recruited at first antenatal care visit from 5 clinics implementing PMTCT (61\%) and from 5 communities around the 5 clinic areas (39\%). In addition, the mothers or mothers-in-law (70.9\%) and husbands or partners $(58.2 \%)$ of the pregnant women were interviewed at their homes. Results indicate that major potential barriers in implementing PMTCT programmes in a resource poor setting included physical access to the health facility, PMTCT knowledge, stigma and support, HIV testing, and delivery preference.(Rev Afr Santé Reprod 2007; 11[1]:57-66)
\end{abstract}

\section{RÉSUMÉ}

Obstacles à la prévention de la transmission du VIH de la mère à l'enfant (PTME) dans un milieu qui ne dispose pas de ressources nécessaires dans la régon d'Eastern Cape, Afrique du Sud Cette étude avait pour objectif d'examiner la PTME et de décrire des obstacles potentiels qui pourraient affecter l'acceptabilité des interventions en faveur de la PTME dans un milieu qui ne dispose pas de ressources nécessaires en Afrique du Sud. L'échantillon a compris 1534 femmes enceintes qui ont été récruitées au cours de leur première visite anténatale auprès de 5 cliniques qui mettent en pratique la PTME (61\%) et auprès de 5 communautés dans l'environnement des 5 cliniques $(39 \%)$. En plus, les mères ou les belles-mères $(70,9 \%)$ et les maris ou les partenaires $(58,2 \%)$ des femmes enceinte ont été interviews à la maison. Les résultats montrent que les obstacles potentiels majeurs à la réalisation des programmes de la PTME dans un milieu qui ne dispose pas de ressources comprennent l'accès physique à l'établissement de santé, la connaissance de la PTME, la stigmatization et le soutien, l'épreuve du VIH et la préférence de l'accouchement. (Rev Afr Santé Reprod 2007; 11[1]:57-66)

\footnotetext{
KEY WORDS: Access to health facility, barriers, mother to child transmission, resource poor setting, South Africa

*Human Sciences Research Council \& University of Limpopo **Human Sciences Research Council

Correspondence to: Prof Karl Peltzer, Social Aspects of HIV/AIDS and Health, Human Sciences Research Council, PrivateBag X41, Pretoria 0001, South_Africa.Email:KPeltzer@hsrc.ac.za
} 


\section{Introduction}

The package PMTCT for the pilot programme in South Africa included offering all antenatal clients voluntary counseling and rapid HIV testing, infant feeding counselling, single dose nevirapine to those women identified as HIV infected, and their infants, and free formula milk for a period of 6 months for women choosing not to breastfeed. The programme also stipulated that all infants should be followed up and tested for HIV, with a rapid antibody test, at 12 months. In all provinces, except KwaZulu-Natal, counselling and testing was designed as an 'opt in' model whereby individual counselling and testing was offered to all women and undertaken after individual consent. The national policy to test infants at 12 months was made due to fears that waiting until 18 months for the first test would result in a large loss to follow up. Infants that test HIV positive at 12 months or are still being breastfed should be brought back to the clinic for a repeat test at 18 months. The rapid antibody test was chosen due to the high cost of PCR tests and limited laboratory infrastructure at the time the programme was introduced. ${ }^{1}$

Doherty, McCoy and Donohue ${ }^{2}$ evaluated a total of 18 PMTCT pilot sites, 2 in each of the 9 provinces, and found that from overall, 39733 $(85 \%)$ of women who tested received their test results and $14340(30 \%)$ of the women who tested had HIV positive test results, of whom 7853 (55\%) were dispensed nevirapine. The rate of uptake of nevirapine did not differ dramatically across sites and was generally suboptimal. At discharge, 58\% (4196/7237) of HIV positive women expressed an intention to practice exclusive formula feeding, and 42\% (3041/7237) of HIV positive women intended to practice exclusive breastfeeding. The predominant choice of infant feeding across both locations (rural and urban) was formula milk. Of concern was the higher rate of intention to formula feed in rural sites $(67 \%)$ compared with urban sites $(57 \%)$. Very little information is known about the actual infant feeding practices of HIV positive women due to the poor follow up rates under these routine programme conditions. Various other studies have identified potential barriers in the implementation of PMTCT in routine care settings in Africa (e.g.,.4).

The aim of this study was to investigate knowledge of PMTCT and to describe potential barriers that might affect acceptability of interventions for PMTCT in a resource poor rural setting in South Africa.

\section{METHOD}

\section{Design and setting}

A cross-sectional survey was carried out among pregnant women in five clinics offering PMTCT and five surrounding communities in a rural district in the Eastern Cape Province. PMTCT included according to the national protocol: health education on antiretroviral prophylaxis and infant feeding options for pregnant women, voluntary counselling and testing, rapid onsite HIV testing, supply of a nevirapine pack, free formula provision, and PMTCT integrated into antenatal care. $^{5}$

\section{Sample and procedure}

From $1^{\text {st }}$ October 2003 to 30 April 2004, 1534 pregnant women were recruited at first antenatal care visit from 5 clinics implementing PMTCT $(61 \%)$ and from 5 communities around the 5 clinic areas (39\%) in region E, Eastern Cape. In addition, the mothers or mothers-in-law (70.9\%) and husbands or partners $(58.2 \%)$ of the pregnant women were interviewed at their homes (see Table 1).

The study was approved by the Rhodes University Ethics Committee. The researcher obtained informed consent from each woman willing to participate in the research.

Interviews were conducted in isiXhosa by trained professional nurses. 


\begin{tabular}{lll}
\hline & $\mathbf{F}$ & $\mathbf{\%}$ \\
\hline Pregnant women & 1534 & 100 \\
Recruited from clinic at first antenatal care visit & 936 & 61.0 \\
Recruited from community prior to antenatal care visit & 598 & 39.0 \\
Mother (mother-in-laws) & $754(333)=1087$ & $49.2(21.7)=70.9$ \\
Husband (partner) & $361(533)=894$ & $23.5(34.7)=58.2$ \\
\hline
\end{tabular}

Measure

An existing questionnaire ${ }^{6}$, containing both closed and open-ended questions, was used. It provided for the following categories of data: demographic and socioeconomic data (9 items), availability of water, transport and communication (8 items), exposure to PMTCT components and HIV knowledge (14 items), stigma and family/ community support for pregnancy (14 items), delivery options ( 3 items), and feeding options (4 items). The questionnaire had been developed and piloted in an earlier study on PMTCT in Gauteng Province. ${ }^{6}$ In addition, PMTCT monitoring data were collected from the hospital coordinating the five PMTCT sites.

\section{Data analysis}

For the closed-ended questions descriptive statistics were calculated using SPSS version 12. For the open-ended questions a thematic analysis was used to analyse and interpret the data.

\section{RESULTS}

Results are divided into (1) sample characteristics, (2) access to health facility, (3) PMTCT knowledge, (4) stigma and support, (5) Voluntary Counselling and Testing (VCT), (6) delivery preference, and (7) infant feeding options.

\section{(1) Sample characteristics}

Almost all of the pregnant women were Xhosa by ethnicity $(96.9 \%)$. The mean age of pregnant women was 25.3 years ( $\mathrm{SD}=7.4$ years), with a range of 10 to 53 years and $20.9 \% 18$ years and younger. Two-thirds of pregnant women (60\%)

African Journal of Reproductive Health Vol. 11 No.1 April, 2007 were never married and one-thirds (36.6\%) were married or co-habiting. Almost half lived with their parents (49\%) and a quarter (24.2\%) lived with their husband or partner. The mean number of years of formal education was 6.0 years $(\mathrm{SD}=3.0$ years) among the pregnant women. This was higher than among their mothers or in-laws (4.4. years) but lower than among their husbands or partners (7.5 years). Three-quarters (71.8\%) lived in a traditional African hut while one-quarter $(27.4 \%)$ lived in a brick house. Only a few of the women $(16.9 \%)$ were formally employed (see Table 2).

\section{(2) Access to health facility}

The most common means of transport to get to a hospital or clinic was walking $(56 \%)$, followed by bus $(42 \%)$ and taxi $(41 \%)$. The time to get to the nearest clinic was for almost one-thirds $(30.4 \%)$ more than one hour and the time to get to the nearest hospital was for the majority $(61.8 \%)$ more than one hour. Only a quarter of the women had access to a telephone (see Table 3).

On an open-ended question participants were asked about "What assistance can be given to you to attend antenatal clinic?" Most (982, 66.3\%) indicated that they wanted money for the bus fare and some wanted better ambulatory services for delivery $(273,18.4 \%)$ and transport availability of taxis and buses $(210,14.2 \%)$.

\section{(3) PMTCT Knowledge}

In this study most pregnant women, mothers/ in-laws and husbands/partners had relevant HIV knowledge but only one-third were aware of PMTCT (see Table 4). 


\section{Table 2: Sample characteristics}

\begin{tabular}{|c|c|c|c|c|}
\hline Items & $f$ & $\%$ & $M$ & $S D$ \\
\hline Age: pregnant women (range 10-53yrs); (321<19 yrs, 20.9\%) & 1543 & 100 & $25.3 \mathrm{yrs}$ & 7.4 yrs \\
\hline Age: mother/in-laws & & & 56 yrs & $10.3 \mathrm{yrs}$ \\
\hline Age: husbands/partners & & & 31 yrs & $9.2 \mathrm{yrs}$ \\
\hline Educational level: pregnant women (from $0=$ no schooling & & & $6.0 \mathrm{yrs}$ & $3.0 \mathrm{yrs}$ \\
\hline to $14=$ university degree); $110(7.2 \%)$ no schooling & & & & \\
\hline
\end{tabular}

\begin{tabular}{|l|l|l|}
\hline Educational level: mother/in-laws & 4.4 yrs & 3.5 yrs \\
\hline Educational level: husbands/partners & $7.5 \mathrm{yrs}$ & $3.4 \mathrm{yrs}$ \\
\hline Ethnicity & & \\
\hline Xhosa & 1457 & 96.9 \\
\hline Zulu and other & 46 & 3.1 \\
\hline Marital status & & \\
\hline
\end{tabular}

\begin{tabular}{|l|l|c|}
\hline Never married & 908 & 60.0 \\
\hline Married as only wife & 480 & 31.1 \\
\hline Married with one or more co-wives & 51 & 3.3 \\
\hline Co-habiting & 33 & 2.2 \\
\hline Widowed & 32 & 2.1 \\
\hline Divorced or separated & 10 & 0.7 \\
\hline
\end{tabular}

Dependents

\begin{tabular}{|l|l|l|}
\hline Number of dependents & 6.0 & 3.4 \\
\hline Number of natural children & 1.7 & 2.4 \\
\hline
\end{tabular}

Type of dwelling

\begin{tabular}{|l|l|l|}
\hline Lives in brick house & 414 & 27.4 \\
Lives in traditional African hut (round mud house) & 1085 & 71.8 \\
\hline In an outside room/house in backyard/in a shack or Mkbukhu & 9 & 0.8 \\
\hline
\end{tabular}

With whom do you live?

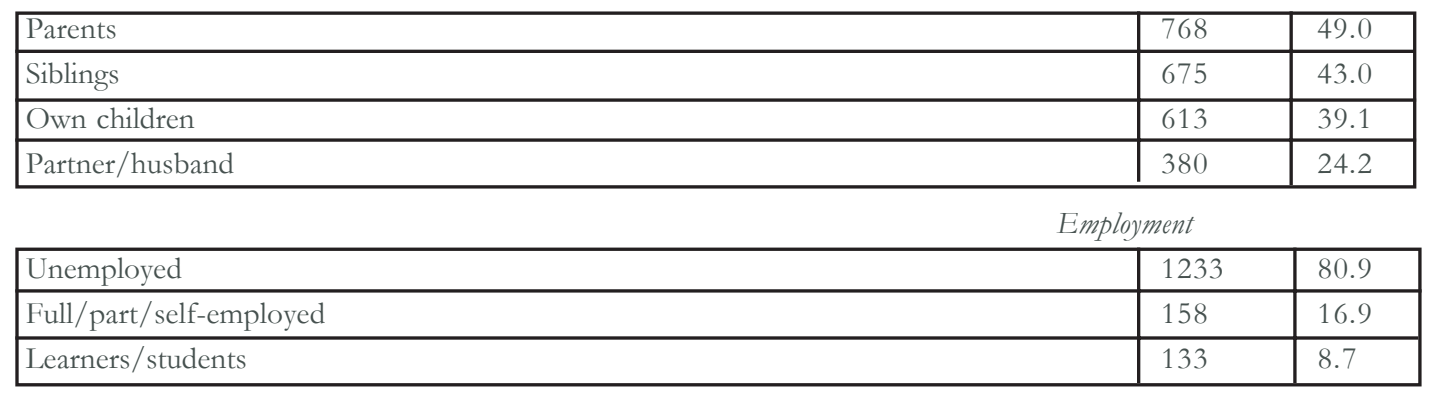

\section{(4) Stigma and support}

More than one-thirds of the participants felt that PLWHAs are stigmatized in their community (see Table 5).
Mothers/in-laws and husbands/partners of the pregnant women interviewed indicated in an open-ended question that emotional support, love and hope for the future, followed by good diet 


\section{Table 3: Access to transport and communication}

\begin{tabular}{|c|c|c|}
\hline Mode of transport to get to hospital/clinic & $f$ & $\%$ \\
\hline Walk & 877 & 55.9 \\
\hline Bus & 658 & 42.0 \\
\hline Taxi & 648 & 41.3 \\
\hline Own car & 3 & 0.2 \\
\hline Hired car & 15 & 1.0 \\
\hline Hitch-hiking & 73 & 4.7 \\
\hline Cart & 15 & 1.0 \\
\hline \multicolumn{3}{|c|}{ Time to get to nearest clinic } \\
\hline 30 minutes and less & 367 & 23.9 \\
\hline$>30$ minutes to 1 hour & 624 & 40.7 \\
\hline$>1$ hour to $1 \frac{1}{2}$ hours & 194 & 12.6 \\
\hline$>1 \frac{1}{2}$ hours & 273 & 17.8 \\
\hline
\end{tabular}

Time to get to nearest hospital

\begin{tabular}{|c|c|c|c|}
\hline 30 minutes and less & 15 & & 10.1 \\
\hline$>30$ minutes to 1 hour & 37 & & 24.1 \\
\hline$>1$ hour to $1 \frac{1}{2}$ hours & 29 & & 19.2 \\
\hline$>11 / 2$ hours & 65 & & $\overline{42.6}$ \\
\hline \multicolumn{4}{|c|}{ Cost of one-way trip to nearest clinic } \\
\hline$<\mathrm{R} 5.00$ & 33 & & 22.1 \\
\hline$>$ R 5.00 to R 10.00 & 58 & & 38.2 \\
\hline \multirow[t]{2}{*}{$>\mathrm{R} 10.00$} & 39 & & 25.7 \\
\hline & $\begin{array}{l}\text { Access to telephone } \\
\text { If yes, access at night }\end{array}$ & 362 & 24.8 \\
\hline Own phone & 64 & & 4.2 \\
\hline Other private phone & 38 & & 2.4 \\
\hline Public phone & 91 & & 5.9 \\
\hline
\end{tabular}

and ARVs are the most important needs of persons living with HIV/AIDS (see Table 6). Insert Table 6 about here

\section{(5) Voluntary Counselling and Testing (VCT)}

Most pregnant women (92.4\%) and their husbands or partners (84\%) in this sample indicated that they never have had an HIV test (92.4\%). Majors barriers of pregnant women for not having had an HIV test were fear of being HIV positive, not aware where to get tested and lack of confidentiality of test results. Having been provided with HIV / AIDS information, wanting to know their HIV status and concern for the transmission of HIV from mother to the unborn child were given as major factors that would encourage them to go for an HIV test. Most mothers or mothers-in-law $(834,98.9 \%)$ and husbands or partners $(767,95.3 \%$ ) would encourage their daughter or wife respectively to go for an HIV test (see Table 7).

Insert Table 7 about here

\section{(6) Delivery preference}

Most pregnant women $(95.5 \%)$, their mothers or mothers-in-law $(95.5 \%)$ and husbands or partners $(96.2 \%)$ in this study indicated that they wish a delivery in a health facility. However, from those 
Table 4: HIV knowledge in correct answers and PMTCT awareness

\begin{tabular}{|c|c|c|c|}
\hline & $\begin{array}{l}\text { Pregnant women } \\
\text { in-laws }\end{array}$ & $\begin{array}{l}\text { Mothers / } \\
\text { partners }\end{array}$ & Husbands/ \\
\hline $\begin{array}{l}\text { Can a pregnant woman infected with HIV-AIDS transmit the } \\
\text { virus to her unborn? }\end{array}$ & $1181(78.5 \%)$ & $759(71.7)$ & $611(73.1)$ \\
\hline $\begin{array}{l}\text { Can a woman with HIV-AIDS transmit the virus to her } \\
\text { unborn child through breastfeeding }\end{array}$ & $1331(88.3)$ & $765(72.2)$ & $560(69.1)$ \\
\hline \multicolumn{4}{|l|}{$\begin{array}{l}\text { What can pregnant women do to reduce the risk of transmitting of HIV } \\
\text { to her unborn? }\end{array}$} \\
\hline Take antiretrovirals & $1220(82.4)$ & $807(76.9)$ & $598(70.9)$ \\
\hline Exclusive breast feeding/formula & $8(0.5)$ & $49(4.7)$ & $52(6.2)$ \\
\hline Aware of PMTCT & $528(35.0)$ & $423(40.3)$ & $309(37.3)$ \\
\hline
\end{tabular}

Table 5: How are people living with HIV/AIDS treated in your community? (open-ended question)

\begin{tabular}{|l|l|l|l|}
\hline & Pregnant woman & Mother/in-law & Husband/partner \\
\hline They are stigmatized & $315(21.2)$ & $256(24.6)$ & $258(30.5)$ \\
Ignored/isolated & $261(17.6)$ & $66(6.3)$ & $21(2.5)$ \\
Get community support & $693(46.7)$ & $552(53.0)$ & $421(49.7)$ \\
Other & $195(13.1)$ & $36(3.5)$ & $34(4.0)$ \\
Don't know & $20(1.4)$ & $131(12.6)$ & $111(13.1)$ \\
\hline
\end{tabular}

Table 6: What are needs of persons living with HIV/AIDS (open-ended)

\begin{tabular}{|l|l|l|}
\hline & Mother/in-law & Husband/partner \\
Emotional support, love and hope for future & $472(44.7)$ & $334(39.9)$ \\
Good diet & $227(21.5)$ & $240(28.6)$ \\
ARVs & $84(8.0)$ & $65(7.7)$ \\
Money & $44(4.2)$ & $17(2.0)$ \\
Other & $100(9.5)$ & $60(7.1)$ \\
Don't know & $128(12.1)$ & $123(14.7)$ \\
\hline
\end{tabular}

pregnant women who had delivered before $41.9 \%$ had delivered their last baby at home (see Table 8).

\section{(7) Infant feeding options}

Almost half of the pregnant women (46.3\%) indicated that they intended to do exclusive breast feeding and 37\% replacement feeding, while most mothers or mothers-in law and husbands or partners said that the feeding methods used with the last born was mostly either exclusive breast feeding or mixed feeding (see Table 9).
Most participants (76.1\%) indicated that they get drinking water from a river and one-thirds (34.7\%) from a water hole, which would increase the difficulty of formula feeding (see Table 10). Insert Table 10 about here

\section{Discussion}

As many countries in Africa roll out programmes for the prevention of mother to child transmission of HIV, there is a need to consider potential barriers that these programmes may face in African Journal of Reproductive Health Vol. 11 No.1 April 2007 
Barriers to Prevention of HIV Transmission from Mother to Child (PMTCT) in a Resource poor ...

Table 7: HIV testing and HIV testing attitudes

\begin{tabular}{|c|c|c|c|c|}
\hline & \multicolumn{2}{|c|}{$\begin{array}{l}\text { Pregnant } \\
\text { women }\end{array}$} & \multicolumn{2}{|c|}{$\begin{array}{l}\text { Husbands / } \\
\text { Partners }\end{array}$} \\
\hline & $\mathrm{F}$ & $\%$ & F & $\%$ \\
\hline Did you ever have an HIV test & 114 & 7.6 & 133 & 16.0 \\
\hline Did you find out the results? & 74 & 4.7 & 75 & 4.9 \\
\hline \multicolumn{5}{|l|}{ If not tested, what are the reasons for not having been tested for HIV\# } \\
\hline Did not know where to get tested & 320 & 20.8 & & \\
\hline It's unlikely that I have been exposed to HIV & 48 & 3.2 & & \\
\hline Was afraid to find out if I was HIV positive & 568 & 37.0 & & \\
\hline Do not like needles & 69 & 4.5 & & \\
\hline $\begin{array}{l}\text { Afraid of losing position, insurance, housing, friends, family, } \\
\text { if people knew I was HIV positive }\end{array}$ & 10 & 0.7 & & \\
\hline Lack of transport & 38 & 2.5 & & \\
\hline Did not trust results to be confidential & 131 & 8.5 & & \\
\hline Others, specify: & 95 & 6.2 & & \\
\hline \multicolumn{5}{|l|}{ What will encourage you to go for an HIV test? (open-ended) } \\
\hline Having been provided with HIV-AIDS information & 566 & 38.8 & & \\
\hline I want to know my status & 394 & 27.0 & & \\
\hline $\begin{array}{l}\text { Concerned how to prevent transmission from mother } \\
\text { to unborn child }\end{array}$ & 202 & 13.8 & & \\
\hline Don't want to know my status & 70 & 4.8 & & \\
\hline Want to be sure the results will be confidential & 39 & 2.7 & & \\
\hline To know why I become sick & 25 & 1.7 & & \\
\hline If antiretroviral treatment is available & 14 & 1.0 & & \\
\hline Other & 149 & 10.2 & & \\
\hline
\end{tabular}

\#not asked for husbands/partners

resource poor settings. This study has shown major potential barriers in implementing PMTCT programs in a resource poor setting including pregnant women from health facilities and from the community in rural South Africa. Barriers to PMTCT (the acceptance of antiretroviral prophylaxsis to HIV positive women, facilitybased delivery where improved obstetric practices can be used, and ART for mother and newborn can be supervised, and adherence to "take-home" ART for mother and newborn when given to HIV positive women at ANC), can be attributed to factors such as physical access to the health facility, PMTCT knowledge, stigma and support, VCT, and delivery preference.

Access to health facilities is a problem, especially as regards transport during emergencies. With a geographically dispersed community it is generally difficult to get to the clinics even during the day. About one-third of the sample spends more than one hour to get to the nearest clinic. There is very little public transport, and emergency transport is difficult to contact. Considering that many pregnant women only attend antenatal care once (to get the card so that they can deliver in a health facility), money for bus fare could be provided.

The knowledge of HIV transmission from mother to child was relatively high. However, only one-third were aware of PMTCT. Community and clinic health education should be improved including PMTCT education.

More than one-thirds of the participants felt that PLWHAs are stigmatizedin their community. Mothers/in-laws and husbands/partners of the pregnant women interviewed indicated in an 
Table 8: Delivery and delivery preferences in frequency (and percent)

\begin{tabular}{|c|c|c|c|}
\hline Item & Pregnant woman & $\begin{array}{l}\text { Mother/mother- } \\
\text { in-law }\end{array}$ & $\begin{array}{l}\text { Husband/ } \\
\text { partner }\end{array}$ \\
\hline \multicolumn{4}{|c|}{ Where do you prefer to give birth? } \\
\hline Hospital & $1436(94.3)$ & & \\
\hline Clinic & $19(1.2)$ & & \\
\hline Home & $68(4.5)$ & & \\
\hline \multirow[t]{2}{*}{$\begin{array}{l}\text { If birth at home, would you call a } \\
\text { TBA to assist }\end{array}$} & $1320(88.4)$ & & \\
\hline & $\begin{array}{l}\text { Where, if so, did you deliver } \\
\text { your last baby }(n=995)\end{array}$ & $\begin{array}{l}\text { Where was last born } \\
\text { delivered? }\end{array}$ & \\
\hline Hospital & $548(57.4)$ & $444(41.7)$ & $295(63.2)$ \\
\hline Clinic & $7(0.7)$ & $8(0.8)$ & $3(0.6)$ \\
\hline Home without TBA & $246(25.8)$ & $411(38.6)$ & $109(23.3)$ \\
\hline \multirow[t]{2}{*}{ Home with TBA } & $145(16.1)$ & $201(18.9)$ & $60(12.8)$ \\
\hline & $\begin{array}{l}\text { Where do you want your daughter } \\
\text { to deliver this baby? }\end{array}$ & $\begin{array}{l}\text { Where do you want your wife } \\
\text { or partner to deliver this baby? }\end{array}$ & \\
\hline Hospital & $973(95.5)$ & $787(96.2)$ & \\
\hline Clinic & $19(1.9)$ & $12(1.5)$ & \\
\hline Home & $27(2.6)$ & $19(2.3)$ & \\
\hline
\end{tabular}

Table 9: Feeding options in frequency (and percent)

\begin{tabular}{|l|l|l|l|}
\hline Item & Pregnant woman & $\begin{array}{l}\text { Mother/mother- } \\
\text { in-law }\end{array}$ & $\begin{array}{l}\text { Husband/ } \\
\text { Partner }\end{array}$ \\
\hline & $\begin{array}{l}\text { Feeding methods to } \\
\text { be used }\end{array}$ & $\begin{array}{l}\text { Feeding methods } \\
\text { with last born }\end{array}$ & $\begin{array}{l}\text { Feeding methods with } \\
\text { last born }\end{array}$ \\
\hline Breast feeding exclusively & $709(46.3)$ & $519(34.5)$ & $189(21.1)$ \\
\hline $\begin{array}{l}\text { Replacement feeding (formula or other milks) } \\
\text { exclusively }\end{array}$ & $567(37.1)$ & $172(11.2)$ & $135(15.1)$ \\
\hline $\begin{array}{l}\text { Breast feeding mixed with water, tea, porridge, } \\
\text { rice, formula or animal milks }\end{array}$ & $475(31.0)$ & $439(28.6)$ & $171(19.1)$ \\
\hline $\begin{array}{l}\text { Can boil drinking water if were to do } \\
\text { formula feeding }\end{array}$ & $1496(99.2)$ & & \\
\hline
\end{tabular}

\section{Table 10: Source of drinking water}

Where do you get drinking water?

\begin{tabular}{|l|c|c|}
\hline & $f$ & $\%$ \\
\hline Tap & 188 & 12.3 \\
\hline Pump & 20 & 1.3 \\
\hline River & 1099 & 76.1 \\
\hline Water hole & 535 & 34.7 \\
\hline Water tank & 32 & 2.1 \\
\hline
\end{tabular}


open-ended question that emotional support, love and hope for the future, followed by good diet and ARVs are the most important needs of persons living with HIV/AIDS. In a similar study of pregnant women within the PMTCT programme in Gauteng, Dorkenoo et al. ${ }^{6}$ also found that stigma persists at the family and at community level. Women indicated that their partners and other family members did not support them emotionally. Community education and awareness campaigns on PMTCT are essential components for the success of the programme. Such education should reinforce male involvement and other family members, particularly mothers-in-law, who have influence over the options open to women who are HIV positive.

Monitoring data in the PMTCT project sites show that from the total number of antenatal care first bookers, two-thirds underwent MTCT pre-test counselling and half accepted HIV testing (of which 60-90\% received the results). Interview data from this study identified as major barriers of pregnant women for not having had an HIV test were fear of being HIV positive, not aware where to get tested and lack of confidentiality of test results. Having been provided with HIV/ AIDS information, wanting to know their HIV status and concern for the transmission of HIV from mother to the unborn child were given as major factors that would encourage them to go for an HIV test. Also most mothers or mothersin-law and husbands or partners indicated that they would encourage their daughter or wife respectively to go for an HIV test. In many PMTCT programmes where VCT is available, low community acceptance and use of VCT services is a major barrier to identifying, counselling and treating HIV+ pregnant women and their partners. In combined data from 9 countries in Africa, $43 \%$ of ANC attenders accepted VCT. ${ }^{7}$ Increasing acceptance of VCT may be one of the most effective ways to decrease perinatal transmission. Many factors have been shown to influence the "demand side" of the decision to seek and accept VCT as part of
PMTCT programmes, including fear of stigma, fear of more rapid death once knowing one's HIV status, and unwillingness to participate in an intervention to prevent the baby from getting HIV if no maternal treatment is available. Addressing both supply and demand factors of VCT is essential. Several interventions have been developed to improve the "supply side" of VCT, including manuals to guide VCT counsellors and the development of detailed standards for certification and accreditation of VCT sites. Mechanisms to improve and standardize the content and quality of VCT, the cornerstone of most PMTCT programmes, have been developed and tested. ${ }^{8}$ Doherty et al. ${ }^{1}$ found in South Africa that Provinces with low HIV testing uptake such as the North West (14\%) and the Eastern Cape (34\%) are still struggling to employ lay counsellors. Routine offer of HIV testing with the right to opt out is now tested in the antenatal setting in several African countries such as in Botswana. This 'opt out' approach to HIV testing has substantially increased the uptake of testing in ANC settings.?

A significant proportion of mothers deliver outside the health facility. Health facility-based delivery is helpful to ensure compliance to infant antiretroviral dosing and to ensure the practice of modified obstetric practices that have been shown to reduce MTCT. ${ }^{10}$ O'Mahony and Steinberg ${ }^{11}$ conducted a survey of two hundred women on place of delivery, home delivery practices and antenatal care for the most recent delivery (within the previous 5 years) from randomly selected clusters, obtained from a multistage random sampling process, in rural Transkei, now Eastern Cape. Two-thirds had delivered at home and one-third within the health services. Of those who delivered at home, 62 $(47 \%)$ were alone at the time of delivery while the remainder were assisted by a close relative or neighbour; $38 \%$ had one or more risk factors for obstetric complications.

Use of skilled professional childbirth attendants by all women remains a goal of safe 
motherhood programmes, despite well-known barriers. Increasing use of skilled professional childbirth attendants, facility-based when feasible, should also be a behavioural goal of PMTCT programmes. This would allow timely, supervised receipt of ARVs during the intrapartum period, while at the same time allowing opportunity for quality routine childbirth care, and improved obstetric practice administered by skilled providers. However, partly due to the magnitude of MTCT and the urgency of increasing coverage of PMTCT interventions, and taking into account the childbirth realities in much of rural Africa, many programmes have begun to focus efforts on improving obstetric practices among traditional birth attendants (TBAs) during home-based childbirth. Challenging global consensus on the diminishing need for and role of TBAs, some PMTCT programmes have placed TBAs at the center of efforts to reduce PMTCT in the community. For the most part, this includes reinforcing quality home-based maternity care by TBAs and other family birth attendants and avoidance of home birth practices that could increase MTCT. ${ }^{8}$

One limitation of this study was that mothers were questioned on infant feeding options but were not followed to determine those who eventually chose a specific feeding option. Actual feeding practice would have been more informative than answers to the question on infant feeding intentions. In addition, the rural PMTCT sites were purposefully chosen. Since they were not randomly selected, it is possible that these clinics may not be representative of other resource settings in South Africa.

\section{Acknowledgement}

This study was funded by the Ford Foundation.

\section{REFERENCES}

1. Doherty T, Besser M, Donohue S, Kamoga N, Stoops N, Williamson L \& Visser R. An evaluation of the Prevention of Mother-to-child Transmi- ssion (PMTCT) of HIV initiative in South Africa: lessons and key recommendations. Durban: Health Systems Trust, 2003.

2. Doherty TM, McCoy D \& Donohue S. Health system constraints to optimal coverage of the prevention of mother-to-child HIV transmission programme in South Africa: lessons from the implementation of the national pilot programme. Afr Health Sci 2005; 5(3): 213-218.

3. Bajunirwe F and Muzoora M Barriers to the implementation of programs for the prevention of mother-to-child transmission of HIV: a crosssectional survey in rural and urban Uganda. AIDS Research and Therapy 2005; http:// aidsrestherapy.com/content/2/1/10.

4. Karamagi CAS, Tumwine JK, Tylleskar T \& Heggenhougen KH. Antenatal HIV testing in rural eastern Uganda in 2003: incomplete rollout of the prevention of mother-to-child transmission of HIV programme. BMC International Health and Human Rights 2006; 6: 6.

5. Peltzer K, Mosala T, Dorkenoo E \& Gumede T. Health facility baseline report on Preventing Mother-To-Child Transmission (PMTCT) in a district of the Eastern Cape. Johannesburg: Ford Foundation, 2003.

6. Dorkenoo E, Gumede T, Maluleke K \& Shaikh N. Prevention of mother-to-child transmission: a report of an assessment of a pilot programme in 15 health facilities in Gauteng Province. Cape Town: Human Sciences Research Council, 2003.

7. Bulterys, ML Nolan, DJ Jamieson, K Dominguez, MG (2002) Advances in the prevention of motherto-child HIV transmission: current issues, future challenges. AIDScience, 2(4), February 28, 2002.

8. Moore M. A behavior change perspective on integrating PMTCT and safe motherhood programs: a discussion paper. Washington, D.C.: The Change Project: AED/The Manoff Group, 2003.

9. Nieburg P, Cannell T, Morrison JS. Expanded HIV testing: critical gateway to HIV treatment and prevention requires major resources, effective protections. Washington DC: Center for Strategic and International Studies, 2005.

10. Burke J. Infant HIV infection: acceptability of preventive strategies in central Tanzania. AIDS Educ Prev 200

African Journal of Reproductive Health Vol. 11 No.1 April 2007 